$16^{\text {th }}$ International Conference on

AEROSPACE SCIENCES \& AVIATION TECHNOLOGY,

ASAT - 16 - May 26 - 28, 2015, E-Mail: asat@ mtc.edu.eg

Military Technical College, Kobry Elkobbah, Cairo, Egypt

Tel : +(202) 24025292 - 24036138, Fax: +(202) 22621908

\title{
Improving the organizational lean Culture by using Critical lean Culture Criteria Model, "Case Study"
}

\author{
Dr. SAMEH A. SALAH ${ }^{1}$; Dr. MOUHMOD M. SAYED ${ }^{2}$
}

\begin{abstract}
The desire for organizations to become innovative has led them focusing on manufacturing concepts such as lean manufacturing, which are very important for companies to succeed in the competitive global environment. The culture of an organization, and its applied strategies, varies from one organization to another, and the organizational culture plays an important role for successful implementation of lean concepts and in shaping the company to becoming an effective and competitive business. The Toyota Way lean culture concepts, has became Toyota's core competence and a major part of Toyota's success in being able to continuously improve and remain competitive globally. The core values that make up this culture are important factors in order to become lean. Toyota believes that lean is not just a set of tools to reduce cost for the short term, but building a culture of learning organization that can become adaptable and dynamic for the long term. This paper measure and assess the current organizational critical lean culture criteria, which lead to find new areas of improvement, and investigate a ways to improve them to ensure successful and sustaining implementation of Lean methodology in the organizations. This paper indicates that the existing organizational culture of technical support unit of airplanes can be improved by focusing on mutual respect, training, empowerment and motivation for employees within the company.
\end{abstract}

KEY WORDS: Lean manufacturing, organizational culture, lean culture improvement.

\section{Introduction}

Lean implementation in manufacturing companies is not very successful. Studies on the relationship between the implementation of lean methodology and the organizational culture profile have been conducted by many scholars like [1]. It was noticed that, when understanding more about the culture profile, you can improve the current performance of the company. According to [2], understanding the organizational culture has a powerful effect on improving company's performance and long-term effectiveness. By studying and understanding the current culture profile, a better judgment on future culture maintenance, and then the innovation, is allowed. Therefore, this paper allows understanding the organizational culture criteria of manufacturing companies, which could help in improving their performance. A successful implementation of lean methodologies depends on the involvement of all individuals within an organization.

1. Dr., Brigadier, Dpt. of Research, Armament authority, Cairo, (Sameh1164@yahoo.com).

2. Dr., Dpt. of Industrial Engineering, CIC, Cairo, Egypt, mah_hsh2000@yahoo.com. 
Leadership style, organization vision, customers, suppliers, continuous improvement, mutual respect; all of these could affect the effectiveness of the schemes implemented within an organization. Therefore, it is always important for the top managers to understand the organizational culture of their companies and lead the organization to implement different strategies to achieve company's goal. It was also mentioned by [3], that organizational culture can be regarded as the stimulus of the adoption of various behaviors within an organization. However, there are few studies on organizational lean culture criteria for manufacturing companies. Therefore, this paper will be an important guide for knowing how to improve the current organizational lean culture for successful implementation of Lean manufacturing methodology, firstly the companies must assessing the current lean culture and defined the weaknesses in the lean culture and then search about ways to improve them, and perform another lean culture assessment to ensure that all weaknesses became strengths lean culture.

\section{Literature review}

\section{1. Definition of lean manufacturing}

Lean manufacturing is described by employing continuous improvement processes focusing on the elimination of non-value added steps within the organization [4]. The concept of lean manufacturing was originally developed at Toyota and defined as a combination of the best concepts of mass and craft production. The resultant model focused on the concept of reducing waste throughout the product and people value streams using the Toyota way model values that enable it to become a learning company that is continuously improving and achieving results [5].

\section{2. Organizational culture}

Organizational culture is defined by [6] as the emergent result of the continuing interactions and negotiations about values, meanings properties between the members of the specific organization and with its environment. the organizational culture as a set of shared mental assumptions that guide interpretation and action in organizations by defining appropriate behavior for various situations [7]. Culture content refers to the relative ordering of beliefs, values, and assumptions. Organizations have subcultures as well as the dominant culture. Companies with strong cultures generally perform better than those with weak cultures, but only when the cultural content is appropriate for the organization's environment. Organizations should have adaptive cultures so that employees focus on the need for change and support initiatives and leadership that keeps pace with these changes.

\section{3. Lean culture}

The culture in a work organization by the sum of its individual's work habits and the knowledge of how things are done to stay out of trouble between members of a group, and also the culture for group members is invisible, and it is the things that are given, or "the way we do things around here" [8]. The lean culture as an organizational environment in which the values and behaviors are aligned with the guiding principles of lean management [9]. A Lean culture encourages all workers to contribute ideas, responds quickly to suggestions for improvement, provides a collaborative learning environment, seeks perfection in its products, services and processes, and enjoys the visible support of all employees and leaders, [10].

\section{4. Advantages of measuring the organizational culture}

Discussing the outcome, dialogue and awareness is very important. It will initiate the mental process required to bring about lasting change and intentions will turn into behavior and actual change becomes a fact. The advantages of measuring the organizational culture include the following [11]: 
- People become aware of the current and of the preferred culture.

- Ease to predict which measures of change will turn out to be effective.

- Management will get more grips on change.

- Resistance to change can be anticipated; it will not happen completely.

- encourage employees to use their energy and creativity.

- It is the basis for a step-by-step, systematic change plan.

- Successful, lasting change revitalizes everyone; leading to positive effects.

\section{5. Critical Lean culture Criteria Model (CLCCM)}

CLCCM consists of seven lean culture dimensions, namely: continuous improvement, processed focused, mutual respect and trust, employees involvement, consistency, mission, and adaptability. Each of these lean culture dimensions has different numbers of lean culture criteria, namely: root cause problem solving, standard work, leaders go to Gemba, daily accountability, visual controls, level out the work load, waste reduction, kaizen training, mutual trust, mutual respect, training and learning, empowerment, motivation, team work, communications, visionary leadership, clear goals, customer focus, supplier relationships as shown in figure 1. This model would enable organizations to know if their culture is healthy enough to cope with lean by knowing the weaknesses and strengths of the culture. Furthermore, it is allow leaders to know how far their organizations are from lean culture [12]. This model achieving a simple method to help companies to simply measure and assess their lean culture criteria by developing a group of questions for each lean culture criterion, to express the presence of each lean culture in the organizations. The author used the questionnaire survey method to measure the current state of organizational lean culture (as shown in the appendix A). The results of questionnaire survey was analyzed by using computer program to compute the mean score for the data collection by all respondents contributed to determine the weaknesses and strengths of the organizational lean culture. This should enable the organizations to implement lean system and eventually sustain it for long time.

\section{Research design and methodology}

The Critical Lean Culture Criteria Model [12] was implemented in the technical support unit of Airplanes in order to assess the current level of lean culture by using questionnaire survey. The technical support unit of Airplane responsible for performing maintenance and minor repair for more than one kind of airplanes, it was in the beginning of its lean journey and try to improve its performance activities by applying the lean manufacturing principles and methodology inside its production lines. A plan for the implementation of the Critical Lean Culture Criteria model was constructed, starting with preparation of the questionnaire, data collection, data analysis, the results, determination of the weaknesses and strengths lean culture, and the required training courses needed to improve weaknesses lean culture. 


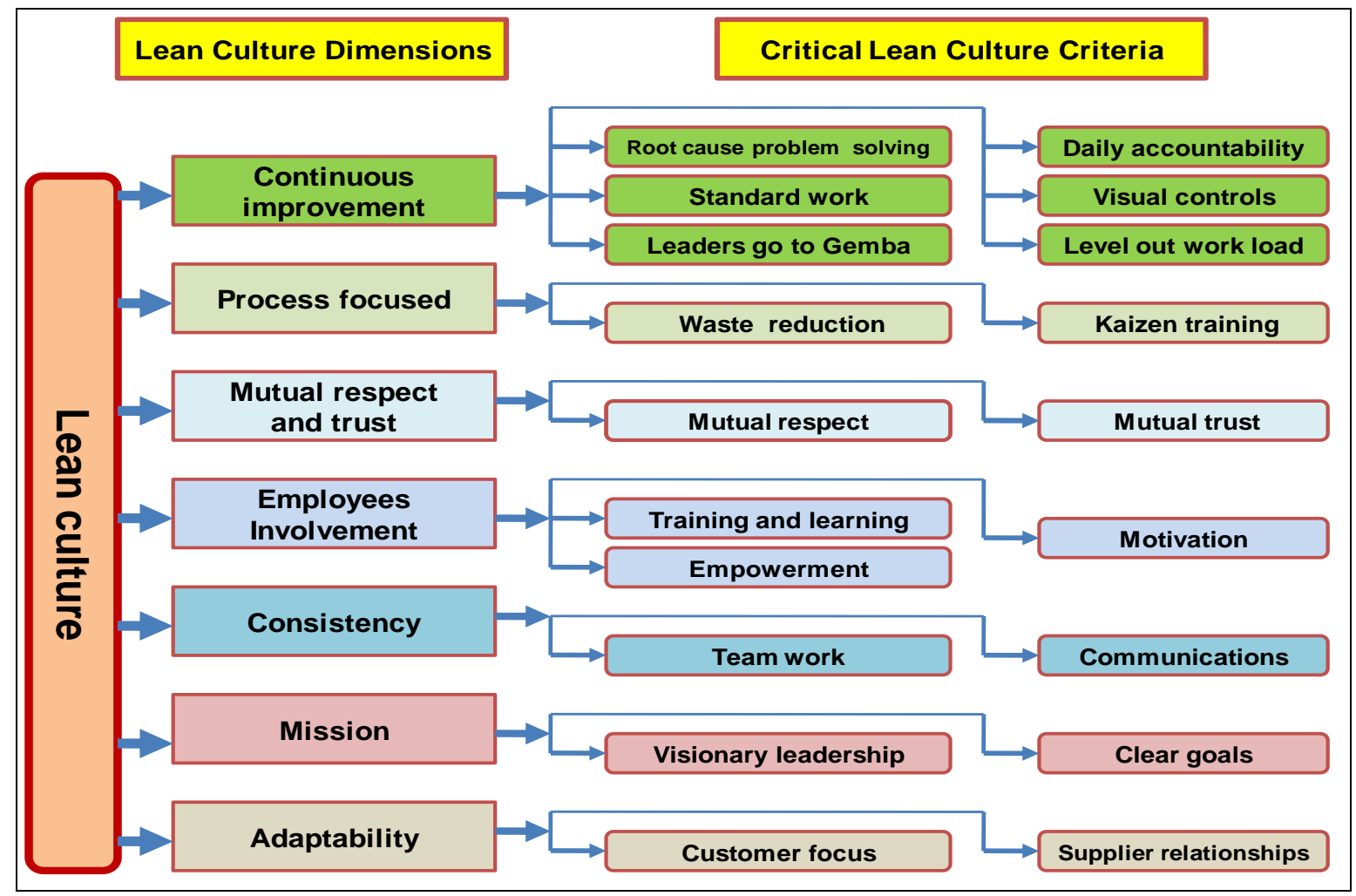

Fig. 1 Critical Lean Culture Criteria Model [12]

\section{1. Analysis of collected data for first assessment}

After performing the first lean culture assessment, then, the organization has a true picture about its lean culture and defined the weaknesses lean culture. The average score and standard deviation for each question, and criterion of the questionnaire for technical support unit of Airplane were calculated. The results showed that twelve lean cultures in the company are conducive to implement Lean principles; and seven lean cultures are considered weaknesses, namely; mutual respect, mutual trust, training and learning, empowerment, motivation, customer focus, and supplier relationship as shown in figure 2. These results are expected, because the company is in the beginning of its lean journey.

\section{2. Analysis of collected data for second assessment}

The technical support unit of Airplane management studied all the seven weaknesses lean culture from the first assessment, and searched about the root cause. The organization concentrated on providing training to leaders and employees by professional instructors, and also, increased the knowledge about the customers, and the suppliers, and made a training session for the leaders and employees in various topics related to weak cultures to improve the areas of weaknesses. The second assessment of the lean culture was carried out after six months from the first assessment, with the same sequence and population of the first assessment; questionnaire to ensure that all weaknesses lean culture became strengths lean culture and had improved and ready to successfully implement lean methodology in the technical support unit. The results showed that all lean culture criteria in the company are improved and considered strengths as shown in figure 3. 


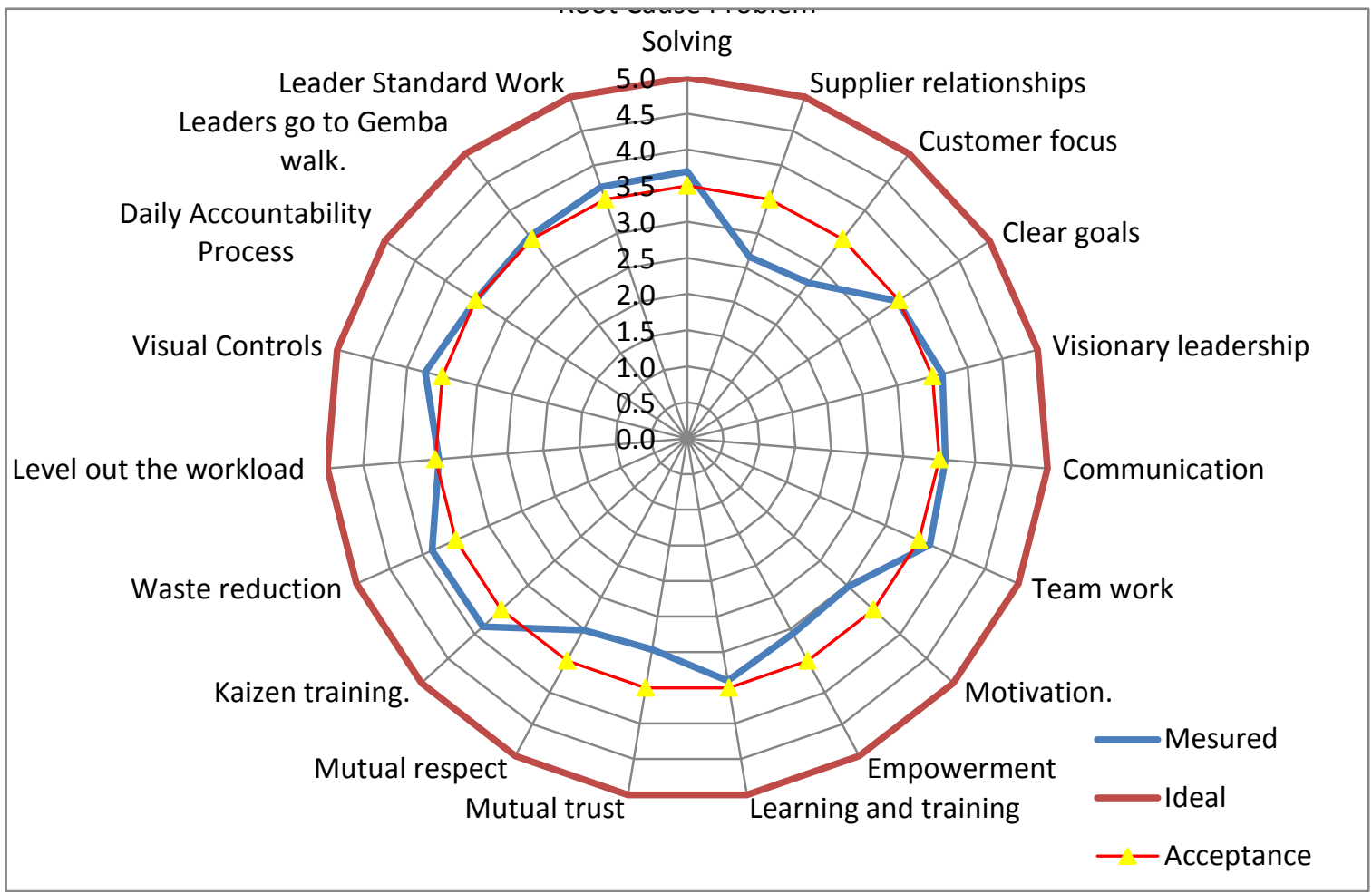

Fig. 2 Results of the first lean culture assessment

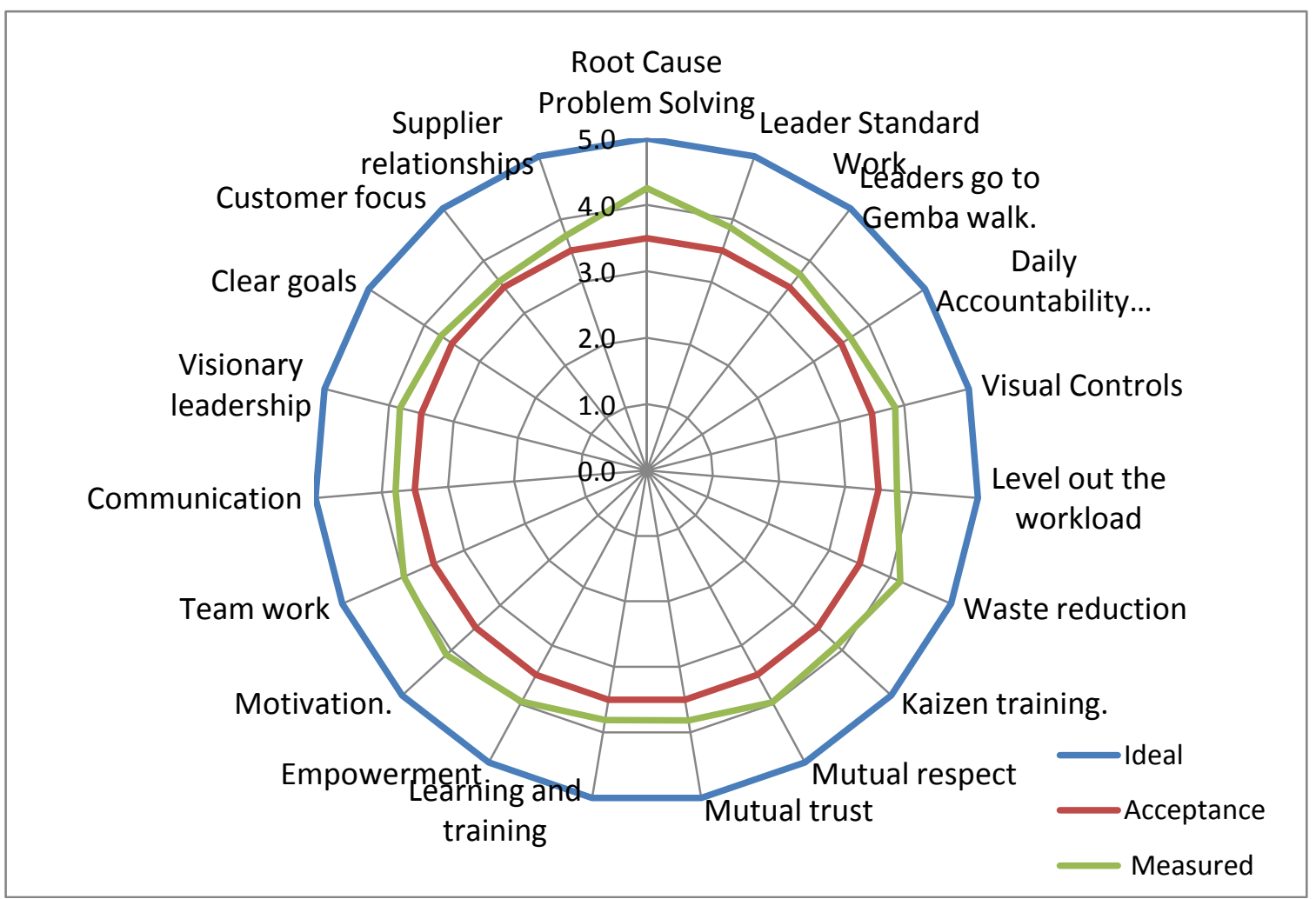

Fig. 3 Results of the second lean culture assessment

\section{3. Improving the organizational lean culture}

Management of the technical support unit of Airplane focused on the following to improve organization weaknesses: 
A. Improve mutual respect, mutual trust criterion:

The organization reviewed the behavior of all leaders towards the respect and trust of the employees, the result was two leaders in the production line have a bad temper, and don't respect the employees. So the morale of the employees became very low. The management changed the two leaders, and carried out training for all leaders on the following:

- Really listen to the employees problems and give them your attention.

- Don't waste time and train employees to focus on finishing the work on time.

- Monitoring the employees and the place the work.

- Building teamwork.

- Building knowledge in problem solving thinking and countermeasures.

- Acknowledge the accomplishments of the employees.

- Don't use authority just because you have it. Encourage your people to make decisions, set their own goals, and take responsibility as often as possible.

- Promote others often and grooming employee's talent.

- Celebrate the success of the employees.

- Commitment for achieving the organization goals.

- Commitment of the employees for achieving their job.

B. Training and learning criterion:

The training course for the employees were reviewed during the last two years, and they found that, there are more than fifty percent of employees didn't have any training, and the person who responsible for training people is not qualified in this field. The management assigned a new qualified engineer for this work, and also, constructed a new modern library and made a plan for all people to visit it and increase their knowledge. Leaders were trained on the following:

- Empowering workers at all levels to act on behalf of the customer.

- Respecting and using the expertise of everyone, and put up a suggestion box that includes a formal system for implementing good suggestions.

- Encouraging risk-taking to test improvement ideas,.

- Using lean to improve the way people do their jobs, not to eliminate jobs.

- Using value stream mapping to show the locations of bottlenecks.

- Building consensus and establishing clear rules that support the mission.

- Get feedback from workers to ensure new rules are realistic.

- Supporting continuous learning for everyone and set a specific goal.

- Making changes to align all organizational structure, with the mission.

C. Empowerment criterion:

The organization reviewed the empowerment in different levels, they found that the empowerment is not activated, and the process of enabling or authorizing an individual to think, behave, take action, and control work and decision making in autonomous ways not found in the company. The management trained leaders in the following empowerment:

- Enabling individuals to fully access personal or collective power, authority and to employ that strength when engaging with other employee.

- Encouraging people to gain the skills and knowledge that will allow them to overcome obstacles in life or work environment.

- Encouraging employees to participate in decision making.

- Organizing meetings with all employees to share gain.

- Enabling an individual to think, and take action in his work.

- Delegating tasks clearly and concisely to the employees.

- Inviting feedback from the employees.

D. Motivation criterion: 
Motivation is psychological forces that determine the direction of a person's behavior in an organization. The management reviewed the motivation programs and activities for the employees, and found that, they need major improvement. The organization constructed new systems for employee's motivation; incentive systems, and make them feel excited to come to work every day, and to spend time with leaders and each other. The management trained leaders in the following:

- Trusting and being more transparent with the employees.

- Increase employee participation by implementing quality control circles.

- Helping employees to increase their relevancy levels and loyalty.

- Being open doors and accelerate employee's chances for advancement.

- Allowing the employees to have sustainable impact in the work.

- Creating the opportunity for employee's achievement to leave a long lasting legacy that rewards the organization they serve and for future.

- Making happiness for employees, and happiness fuels ones self-esteem.

- Emphasizing on the importance of the process.

- Providing employees with clear information about the effective performance.

E. Customer focus criterion:

The management reviewed the lean criteria of customer focus, they found that, there wasn't any feedback from the customers, and undefined customer requirements. The organization constructed an incentive system for the customers and website for the company for collecting feedback from the customers, and trained the leaders in the following:

- Gathering information quickly and easily about the customers.

- Improving the customer's service.

- Trying to clear the customer requirements for everyone in the organization.

- Developing methods for collecting feedback from the customers.

- Investigating systems to predict the customer requirements.

- Providing training for employees in how to change to meet customer requirements in minimum time available.

- Developing metrics for measuring the success from customer point of view.

- Organizing regular meetings with customer.

- Constructing an update file for customers' ideas and requirements.

F. Supplier relationship criterion:

Suppliers' relationship is discipline of strategically planning for, and managing, all interactions with suppliers that supply goods and/or services to an organization in order to maximize the value of those interactions. The organization reviewed the strategic plan for the suppliers; the results showed that, the strategic plan for the suppliers was not activated. The management activates the strategic plan for the suppliers, and constructed a communication channels to share the feedback. The management provided training for leaders in the following:

- Developing methods for collecting feedback from the partners and suppliers.

- Organizing regular meetings with partners and suppliers.

- Decrease the number of suppliers.

- Informing the suppliers to provide accepted materials according to the specifications for greater efficiency, better quality, and access to innovation.

- Being careful when selecting the suppliers.

- Planning meetings, with the suppliers.

- Review the operational performance and risks with the suppliers. 


\section{Results and discussion}

The Critical Lean culture Criteria Model has been implemented in the technical support unit of Airplanes to define the weaknesses lean culture and helping them to find a new areas of improvement for successful lean transformation. This model helped the organization to face their basic underlying assumption and to know how far they are from a lean culture, and knowing a new method to measure it. The obtained results from first assessment as shown in figure 3 indicated that, there are eleven lean culture criteria have calculated average scores above " 3.5 " and considered strength lean culture; and seven lean culture criteria have calculated average scores below " 3.5 ", and considered weaknesses lean culture. The weaknesses lean culture namely; mutual respect, mutual trust, training and learning, empowerment, motivation, customer focus, and supplier relationship. The obtained results from the second assessment as shown in figure 4 indicated that, all seven weaknesses lean culture had improved and became strengths by providing suitable awareness and training to leaders and employees by professional instructors.

\section{Conclusion}

The innovative organizations has led them to focus on lean manufacturing, which are very important for companies to succeed in the competitive global environment. A successful implementation of lean methodologies depends on the involvement of all individuals within an organization. This paper provides a new method to improve the organizational lean culture. This method involves carefully recognize the current organizational lean culture by using the Critical Lean culture Criteria Model and define the weaknesses lean culture and try to develop ways to improve them. The employees are the major resources of any organizations, then the management must focuses on develop; learning, respect and trust, motivate, empower them for successful and sustainable implementation of lean manufacturing methodology.

\section{References}

[1] Dellana, S.A. and Hauser, R.D., 1999. "Towards defining the quality culture", Engineering Management Journal.

[2] Cameron, K.S. and Quinn, R.E., 1999. "Diagnosing and changing organizational culture: based on the competing values framework", Addision-Wesley Publishing.

[3] Liu, A. and Zhang, S.B., 2004. "Organizational culture profiles of the construction enterprises in china", 4th World Congress on Cost Engineering, Project Management, and Quantity Surveying, the International Cost Engineering Council, South Africa.

[4] McGivern, M.H. \& Stiber, A., 2008. "Lean manufacturing techniques", http://www.searchuu.com/doc/51304_Lean_Manufacturing_Techniques.

[5] Pieterse, K., 2007. "Leaning the South African way", 2nd ed., Trilean Publishing.

[6] Steel, R., 2004. "Culture and complexity Organizations \& People", Journal of Manufacturing Technology Management, Vol. 7, No. 2.

[7] Ravasi, D., Schultz, M., 2006. "Responding to organizational identity threats: exploring the role of organizational culture", Management Journal, Vol.49, No.3, pp. :433-458.

[8] David Mann, 2005. "Creating a Lean Culture, tools to sustain lean conversion", Productivity Press, a division of The Kraus Organization Limited, New York.

[9] Integris Performance Advisors, 2013. "Achieving Lean Culture in Washington State", website at http://integrispa.com/lean-washington/.

[10] Steve Straub, 2010. "Five ways to promote a lean culture", Lean Office.

[11] OCAI report, 2010, "The Organizational Culture Assessment Instrument”, developed by Kim Cameron and Robert Quinn, www.ocai-online.com. 
[12] Sameh, Nahed, 2014, " investigation of critical lean culture criteria framework for lean transformation ", 16th International Conference on applied mechanics\& mechanical engineering, A.M.M.E, May 27-29, 2014.

\section{Appendix A Questionnaire instructions for assessing the lean culture criteria}

\begin{tabular}{|l|l|}
\hline COMPANY & \\
\hline DATE & \\
\hline DEPARTMENT & \\
\hline
\end{tabular}

Please note the following:

Please answer all questions openly and honestly to ensure accurate results by placing $\mathrm{X}$ on the scale rating which feel that happened in your organization.

Please indicate your level of agreement to the following statements using this scale and take your time for accurate responses:

Please click on a number from 1 to 5 for each statement below:

\begin{tabular}{|c|c|c|c|c|}
\hline 1 & 2 & 3 & 4 & 5 \\
\hline Strongly Disagree & Disagree & Undecided & Agree & Strongly Agree \\
\hline
\end{tabular}

Lean Culture Assessment questionnaire

\begin{tabular}{|c|c|c|c|c|c|c|}
\hline & & Lean Culture Criteria & & & ale & \\
\hline & & & 1. & 2 & & \\
\hline A & & Continuous improvement & & & & \\
\hline A1 & & Root Cause Problem Solving & & & & \\
\hline & 1 & $\begin{array}{c}\text { Are leaders regularly expect cause analysis (five why analysis) and } \\
\text { pursuit of root causes for large and small problems? }\end{array}$ & & & & \\
\hline & 2 & $\begin{array}{l}\text { Is there a routine and systematic use of problem solving tools to seek root } \\
\text { cause solutions? }\end{array}$ & & & & \\
\hline & 3 & Is the process redesigned to avoid occurring of problems? & & & & \\
\hline & 4 & $\begin{array}{r}\text { Are you constantly looking to identify problems or concerns when } \\
\text { performing your job function? }\end{array}$ & & & & \\
\hline & 5 & $\begin{array}{r}\text { Are solutions and corrective actions, implemented effectively and on } \\
\text { time? }\end{array}$ & & & & \\
\hline & 6 & $\begin{array}{r}\text { Are there developed continuous improvement in your organization } \\
\text { through identifying and solving problems? }\end{array}$ & & & & \\
\hline & 7 & $\begin{array}{l}\text { Can you stop the production process if it was discovered that something } \\
\text { was wrong with the process or the product? }\end{array}$ & & & & \\
\hline A2 & & Standard Work & & & & \\
\hline & 1 & Are all leaders carrying and following standard work? & & & & \\
\hline & 2 & Are standard work daily reviewed by next level? & & & & \\
\hline & 3 & Are completed documents visually displayed every day for each leader? & & & & \\
\hline & 4 & $\begin{array}{r}\text { Are the documented standard processes in place, and are accessible to the } \\
\text { employees performing the operations? }\end{array}$ & & & & \\
\hline & 5 & Can leaders identify how standard work is beneficial? & & & & \\
\hline & 6 & $\begin{array}{r}\text { Are you allowed to contribute to improve procedures and work } \\
\text { instructions? }\end{array}$ & & & & \\
\hline & 7 & $\begin{array}{l}\text { Are there clear procedures and work instructions available in your work } \\
\text { area? }\end{array}$ & & & & \\
\hline
\end{tabular}




\section{Appendix A Lean Culture Assessment questionnaire (Cont.)}

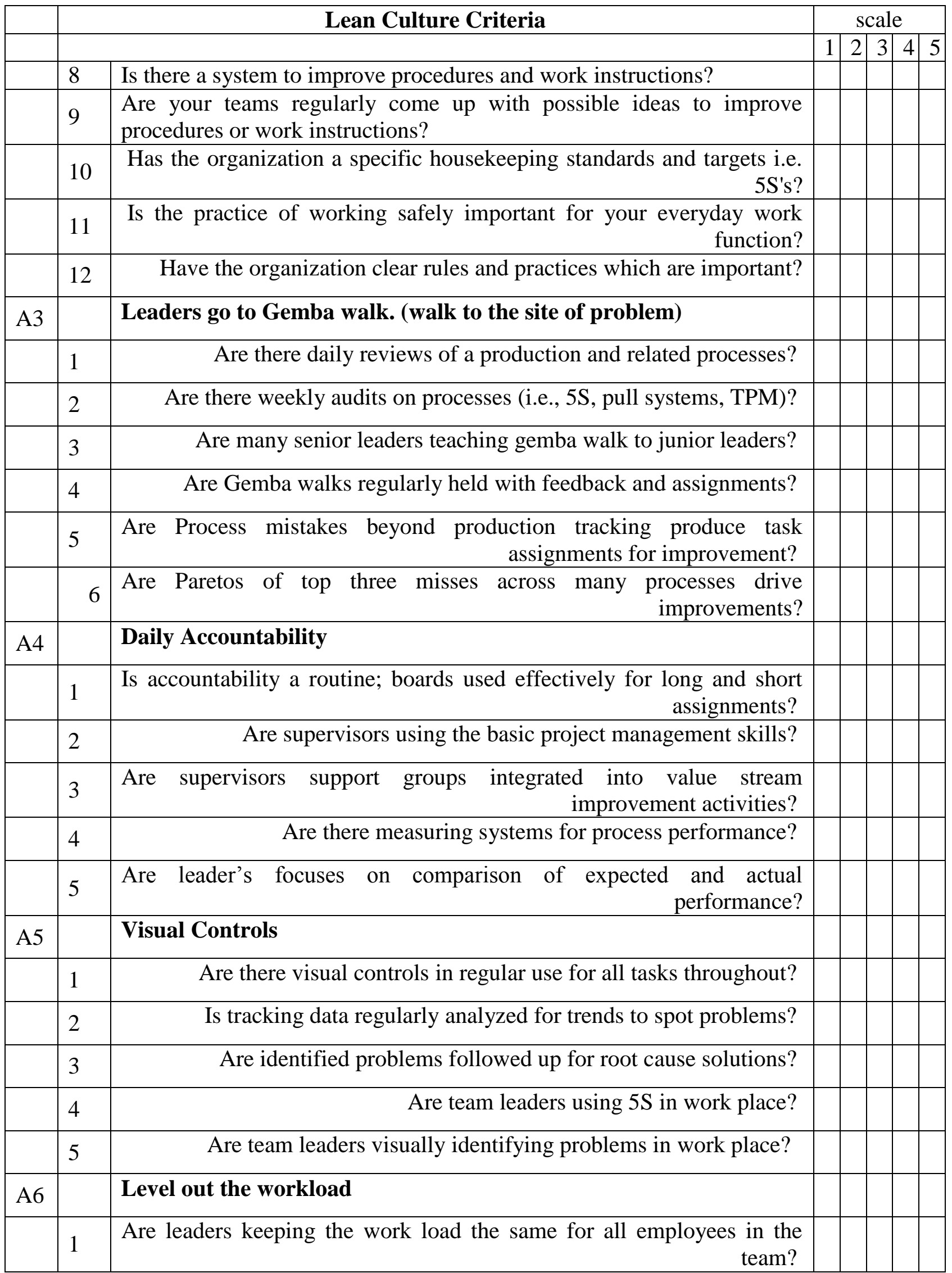




\section{Appendix A Lean Culture Assessment questionnaire (Cont.)}

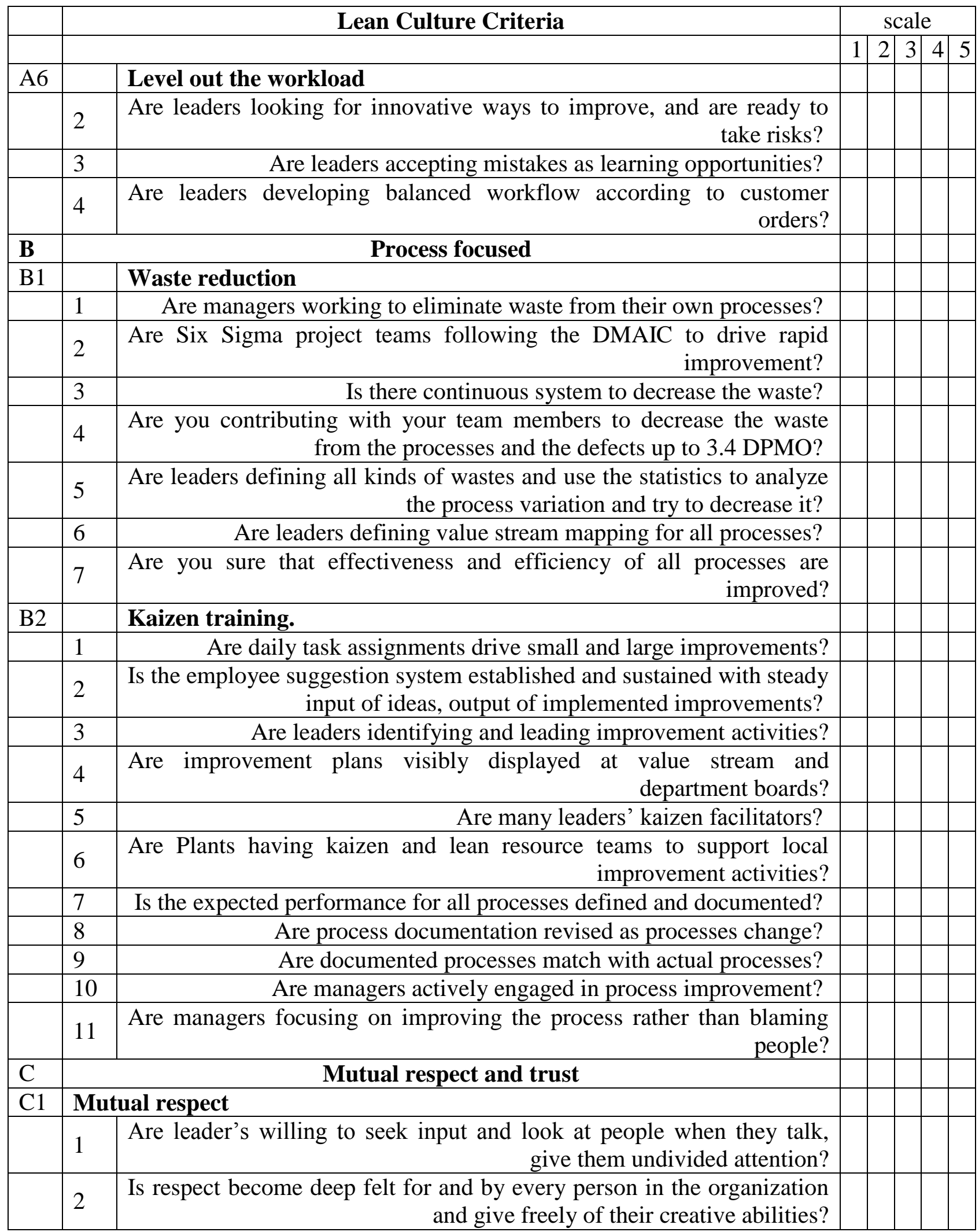




\section{Appendix A Lean Culture Assessment questionnaire (Cont.)}

\begin{tabular}{|c|c|c|c|c|c|c|}
\hline & \multicolumn{2}{|r|}{ Lean Culture Criteria } & \multicolumn{4}{|c|}{ scale } \\
\hline & & & 1 & 2 & & \\
\hline $\mathrm{C} 1$ & \multicolumn{2}{|c|}{ Mutual respect } & & & & \\
\hline & 3 & $\begin{array}{l}\text { Do leaders acknowledge the accomplishments of others then give away } \\
\text { the credit if things go well, and take the fall if things go poorly? }\end{array}$ & & & & \\
\hline & 4 & Are you committed to the main goals of your organization? & & & & \\
\hline & 5 & $\begin{array}{r}\text { Do the organization managers treats all its employees equally with } \\
\text { respect and recognition with their performance? }\end{array}$ & & & & \\
\hline & 6 & Is your team leader treating you with respect and dignity? & & & & \\
\hline & 7 & Is your team leader allowing you to learn and grow from your mistakes? & & & & \\
\hline & 6 & $\begin{array}{r}\text { Are Plants having kaizen and lean resource teams to support local } \\
\text { improvement activities? }\end{array}$ & & & & \\
\hline $\mathrm{C} 2$ & \multicolumn{2}{|c|}{ Mutual trust } & & & & \\
\hline & 2 & Do employees report failure without fear of blame? & & & & \\
\hline & 3 & Are you respected and trusted by your fellow employees? & & & & \\
\hline & 4 & Is there high trust between employees and managers? & & & & \\
\hline & 5 & Is the performance appraisal true for all processes and employees? & & & & \\
\hline $\mathrm{D}$ & \multicolumn{2}{|r|}{ Employees Involvement } & & & & \\
\hline D1 & \multicolumn{2}{|r|}{ Learning and training } & & & & \\
\hline & 1 & $\begin{array}{r}\text { Are leader's willing to seek input and look at people when they talk, } \\
\text { give them undivided attention? }\end{array}$ & & & & \\
\hline & 2 & $\begin{array}{r}\text { Is respect become deep felt for and by every person in the organization } \\
\text { and give freely of their creative abilities? }\end{array}$ & & & & \\
\hline & 1 & $\begin{array}{r}\text { Are leaders grooming talent for employees and ensure that the } \\
\text { innovation of team members has success to match or even surpass the } \\
\text { organization goals? }\end{array}$ & & & & \\
\hline & 2 & $\begin{array}{r}\text { Is every employee involved in running the business and helping the } \\
\text { organization to meet its goals? }\end{array}$ & & & & \\
\hline & 3 & $\begin{array}{r}\text { Is the organization focusing on upgrading workers' skills and knowledge } \\
\text { to improve efficiency and customer service? }\end{array}$ & & & & \\
\hline & 4 & $\begin{array}{r}\text { Are employees well informed of the current company development } \\
\text { policies? }\end{array}$ & & & & \\
\hline & 5 & $\begin{array}{c}\text { Are leaders insisting to encourage employees to build knowledge in } \\
\text { problem solving thinking and countermeasures? }\end{array}$ & & & & \\
\hline & 6 & Are employees having appropriate training related to their work? & & & & \\
\hline & 7 & Is there annual assessment for your training needs? & & & & \\
\hline & 8 & Are the training repeated for you every period of time? & & & & \\
\hline \multirow[t]{3}{*}{$\mathrm{D} 2$} & \multicolumn{2}{|c|}{ Empowerment } & & & & \\
\hline & 1 & $\begin{array}{r}\text { Is the number of ideas generated per week from employees for problem } \\
\text { solving equal to the number of employees? }\end{array}$ & & & & \\
\hline & 2 & $\begin{array}{r}\text { Does your manager monthly "Share the Gain" meetings with all } \\
\text { employees? }\end{array}$ & & & & \\
\hline
\end{tabular}




\section{Appendix A Lean Culture Assessment questionnaire (Cont.)}

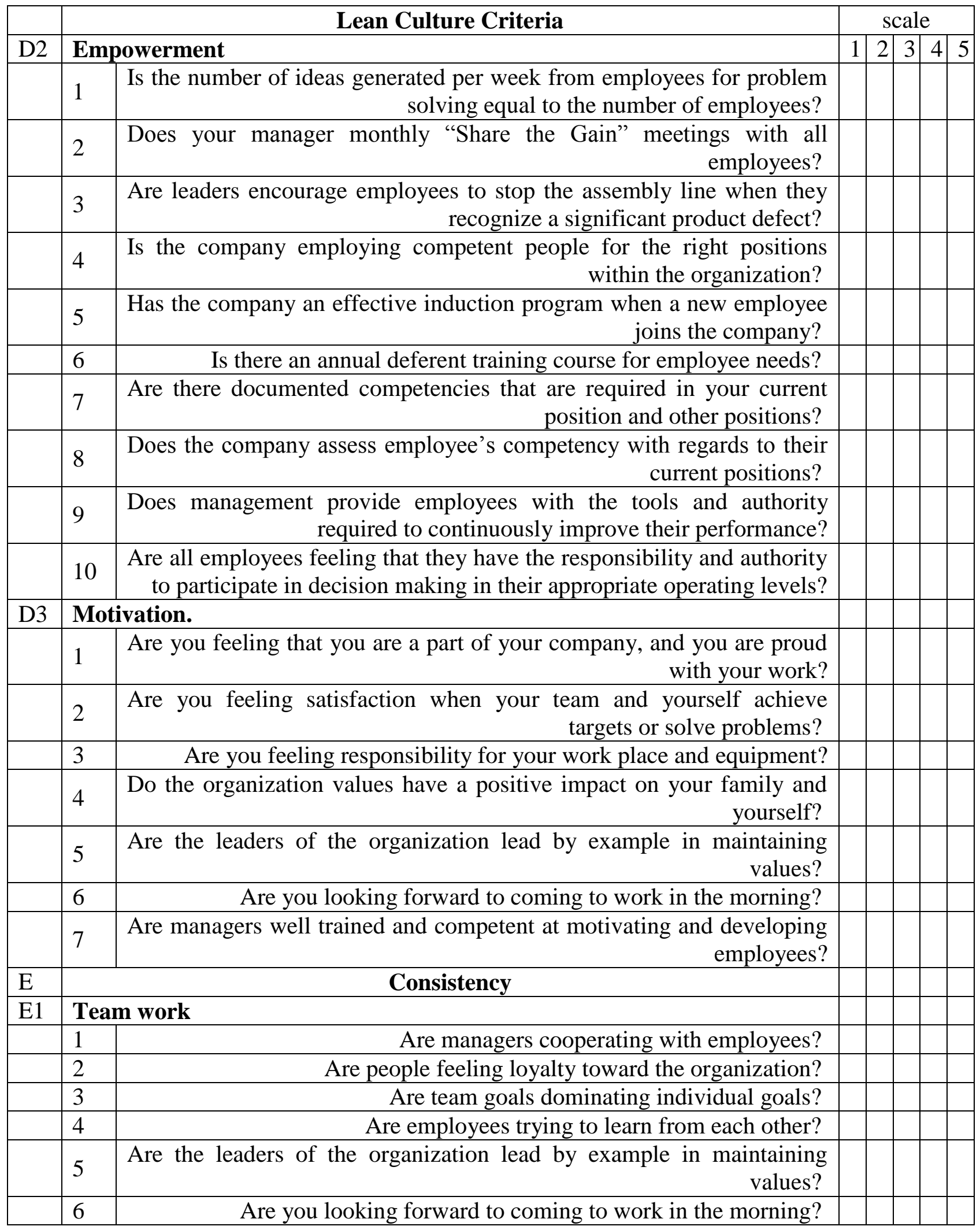




\section{Appendix A Lean Culture Assessment questionnaire (Cont.)}

\begin{tabular}{|c|c|c|c|c|c|c|}
\hline & & Lean Culture Criteria & & & ale & \\
\hline E1 & Tes & n work & 1 & 2 & & \\
\hline & 7 & $\begin{array}{r}\text { Does your team have clear goals and targets that are aligned to the } \\
\text { organizational goals and targets? }\end{array}$ & & & & \\
\hline & 8 & $\begin{array}{c}\text { Does your team leader facilitate problem solving sessions when } \\
\text { problems have been identified? }\end{array}$ & & & & \\
\hline & 9 & Does your team regularly identify and solve problems? & & & & \\
\hline & 10 & Are various teams aligned and work together towards a common goal? & & & & \\
\hline & 11 & Are you feeling happy as a member of your team? & & & & \\
\hline & 12 & Does the company provide team-based recognition and rewards? & & & & \\
\hline & 13 & $\begin{array}{r}\text { Are your team leader provides a good coaching role and allows you to } \\
\text { grow in your current position? }\end{array}$ & & & & \\
\hline & 14 & $\begin{array}{c}\text { Is training performed by team leader satisfactory to your job } \\
\text { requirements? }\end{array}$ & & & & \\
\hline & 15 & Is the leader sending the customers' feedback to all employees? & & & & \\
\hline E2 & & Communication & & & & \\
\hline & 1 & $\begin{array}{r}\text { Is there a clear communication channel that effectively communicates } \\
\text { the company's objectives and performance? }\end{array}$ & & & & \\
\hline & 2 & $\begin{array}{c}\text { Are you informed with formal and informal events happening in the } \\
\text { company? }\end{array}$ & & & & \\
\hline & 3 & $\begin{array}{c}\text { Are you able to openly communicate on issues with team leader, } \\
\text { manager or HR department? }\end{array}$ & & & & \\
\hline & 4 & Are you receiving feedback on ideas and issues that you have raised? & & & & \\
\hline & 5 & $\begin{array}{r}\text { Are you feeling comfortable that you can discuss problems with your } \\
\text { team leader or manager? }\end{array}$ & & & & \\
\hline & 6 & $\begin{array}{r}\text { Are all employees regularly given feedback on safety incidents and their } \\
\text { corrective actions? }\end{array}$ & & & & \\
\hline & 7 & $\begin{array}{r}\text { Are employees receiving regular feedback on quality issues from } \\
\text { customers? }\end{array}$ & & & & \\
\hline $\mathrm{F}$ & & Mission & & & & \\
\hline F1 & Vis & onary leadership & & & & \\
\hline & 1 & $\begin{array}{c}\text { Are leaders communicating the organization's vision for the future and } \\
\text { focuses on the leadership team? }\end{array}$ & & & & \\
\hline & 2 & Are leaders changing for better interaction with employees? & & & & \\
\hline & 3 & $\begin{array}{r}\text { Are leaders identifying the major barriers for achieving the organization } \\
\text { vision? }\end{array}$ & & & & \\
\hline & 4 & $\begin{array}{c}\text { Are employees sharing their ideas to reduce waste and improve } \\
\text { processes? }\end{array}$ & & & & \\
\hline & 5 & Are leaders clarifying vision, mission and values of the organization? & & & & \\
\hline & 6 & $\begin{array}{r}\text { Are supervisors interconnecting the goals and metrics to departmental } \\
\text { team and individual levels? }\end{array}$ & & & & \\
\hline & 7 & $\begin{array}{r}\text { Does management commit with time and resources to improve the } \\
\text { relationships with customers? }\end{array}$ & & & & \\
\hline
\end{tabular}




\section{Appendix A Lean Culture Assessment questionnaire (Cont.)}

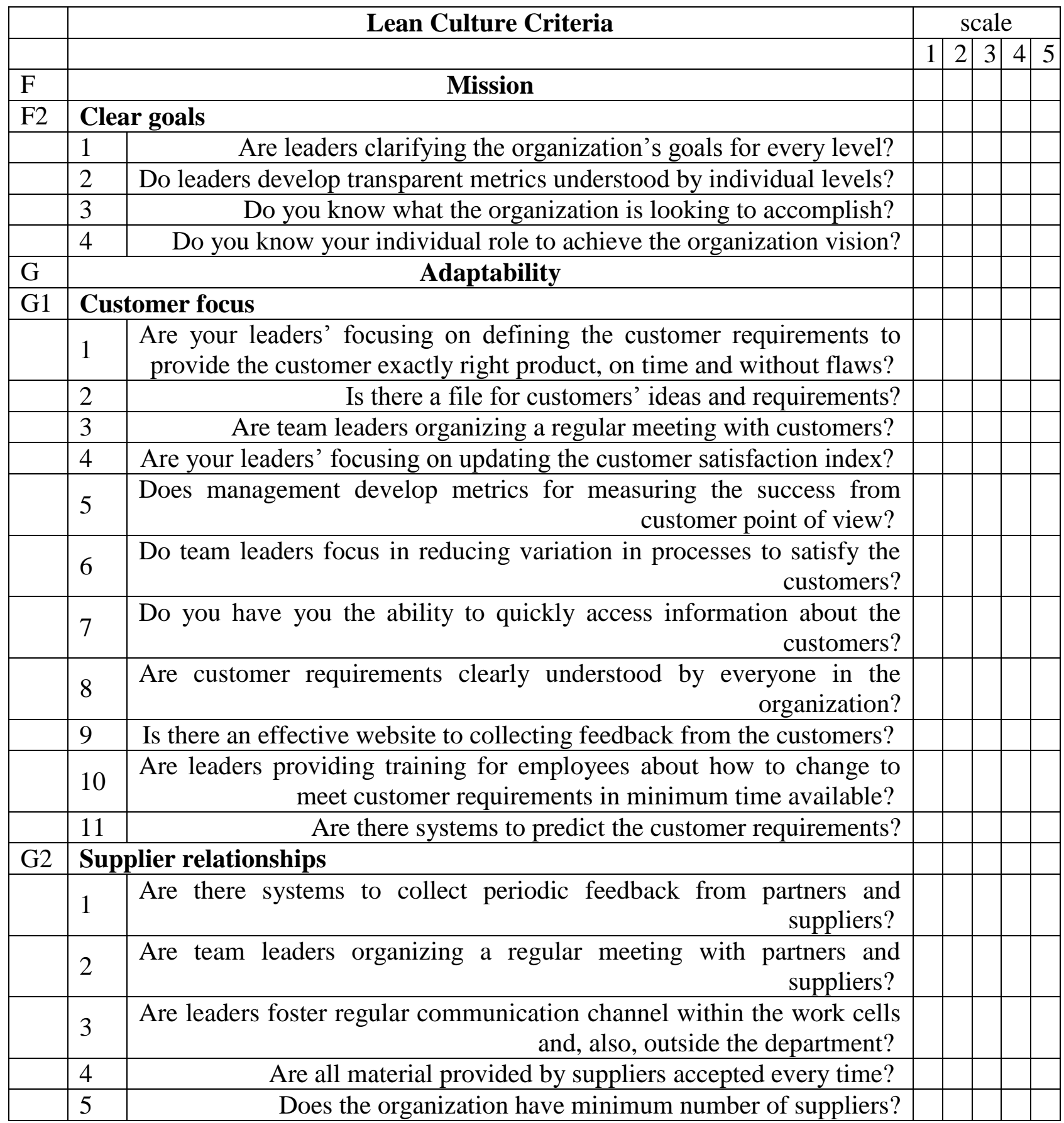

